\title{
EVALUATION OF BNL PILE GRAPHITE
}

Price $\$ 0.25$

Available from the

Office of Technical Services

Department of Commerce

Washington 25, D. C.

\section{October 5, 1953}

\begin{abstract}
Written By:
W.L. Kosiba

D.H. Gurinsky

G.J. Dienes
\end{abstract}

Work Done By:

Stored Energy - W.L. Kosiba

Physical Growth - E.E. Walsh

X-Ray - O.F. Kammerer, J. Sadofsky

\section{LEGAL NOTICE}

This report was prepared as an account of Government sponsored work. Neither the United States, nor the Commission, nor any person acting on behalf of the Commission:

A. Makes any warranty or representation, express or implied, with respect to the accuracy, completeness, or usefulness of the information contained in this report, or that the use of any information, apparatus, method, or process disclosed in this report may not infringe privately owned rights; or

B. Assumes any liabilities with respect to the use of, or for damages resulting from the use of any information, apparatus, method, or process disclosed in this report.

As used in the above, "person acting on behalf of the Commission" includes any omployee or contractor of the Commission to the extent that such employee or contractor prepares, handles or distributes, or provides access to, any information pursuant to his employment or contract with the Commission.
CLASSIFICATION CANCELLED.

DATE

FEB 131957 m $^{\mathscr{U}}$

For The Atomic Energy Commiesion

- H it Oanava

Chiof, Declassiflcation Branoh

$$
\begin{gathered}
\text { BROOKHAVEN NATIONAL LABORATORY } \\
\text { Upton, N.Y. }
\end{gathered}
$$



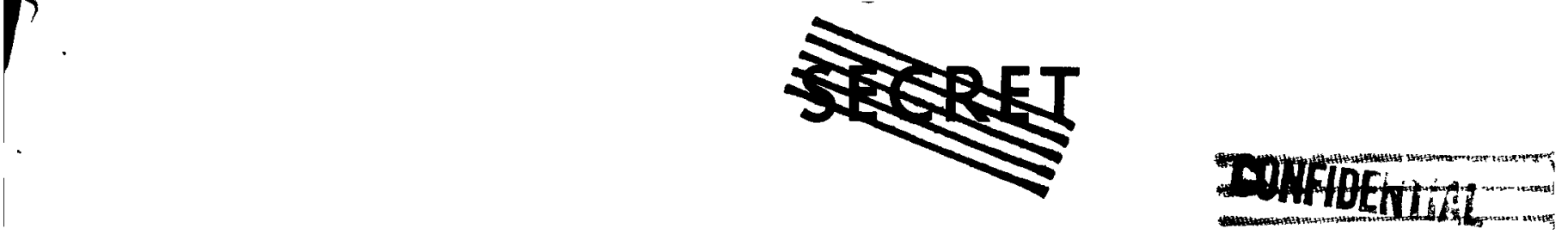

\author{
ABSTRACT \\ The graphite in the Brookhaven reactor was evaluated with \\ respect to the following properties: \\ 1) stored energy, \\ 2) physical growth, and \\ 3) c-axis change. \\ As a result of these studies, it is believed that: \\ 1) The temperature of the graphite in the BNL pile may be \\ raised to $250^{\circ} \mathrm{C}$ or even $400^{\circ} \mathrm{C}$ without an excessive tem- \\ perature excursion. \\ 2) The low temperature stored energy in the BNL pile gra- \\ phite may be safely released. \\ 3) Some growth recovery should be expected. \\ 4) It is desirable to anneal the BNL pile.
}

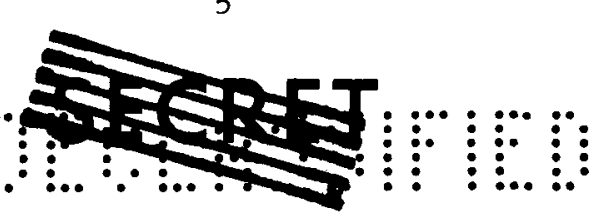




\section{EVALUATION OF BNL PILE GRAPHITE}

\section{Introduction}

The studies on BNL pile graphite prior to this investigation were in the nature of monitoring rather than serious evaluation. The change in dimensions of the pile has been followed by the Operations Division under the direction of $\mathrm{R}$. W. Powell. The growth in the BNL pile at the present time is not a serious concern but is already sufficient to distort the alignment of some of the openings through the graphite structure. It is estimated that within a few years operational difficulties may be experienced if the current rate of growth continues.

The information obtained from the British (BNL Log No. C-6851) strongly suggested that the BNL pile could be safely annealed. In order to determine the desirability and feasibility of such a large scale experiment an evaluation of the Brookhaven pile graphite was undertaken. The program consisted of three parts:

1) stored energy measurements,

2) physical growth measurements, and

3) $x$-ray c-axis measurements.

The stored energy measurements were undertaken to determine the necessity for a planned release of this energy. The physical growth and $x$-ray $c$-axis measurements were undertaken to determine whether recovery of some of the growth and a change in growth rate accompanied an energy release.

\section{Stored Energy Measurements}

\section{Apparatus}

A brass cylinder, 29-1/2 in. long and 4 in. ID with one end closed, was wrapped with a heating coil. This served as the furnace. An iron constantan the rmocouple was

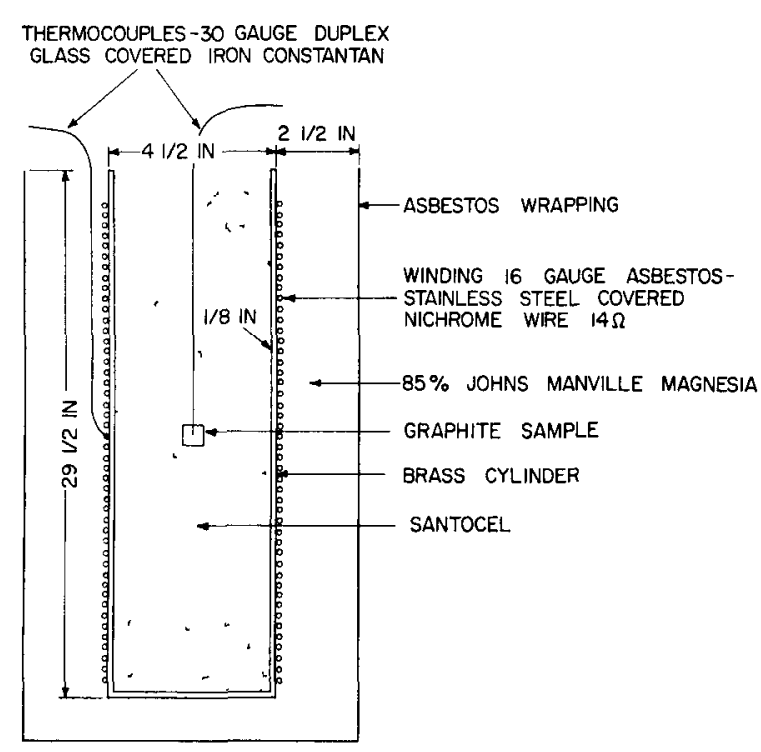

Figure 1. Furnace used for studying release of stored energy. attached at the midpoint of the brass cylinder. Asbestos was wrapped around the furnace as outside insulation and santocel was used as the insulation inside the furnace. The graphite sample with an iron constantan the rmocouple in it was imbedded in the santocel at the midpoint of the furnace. A Loudon controller was used to control the temperature of the furnace. Two identical pieces of apparatus were constructed for more efficient collection of data. (See Figure 1.)

Method of Measurement

Release experiments were run at both 200 and $400^{\circ} \mathrm{C}$. The brass cylinder was raised to $200^{\circ} \mathrm{C}$ or $400^{\circ} \mathrm{C}$ (depending on the run) as rapidly as possible. This took from 10 to $15 \mathrm{~min}$ for the $200^{\circ} \mathrm{C}$ runs and about $35 \mathrm{~min}$ for the run at $400^{\circ} \mathrm{C}$. The temperature of the wall was then 

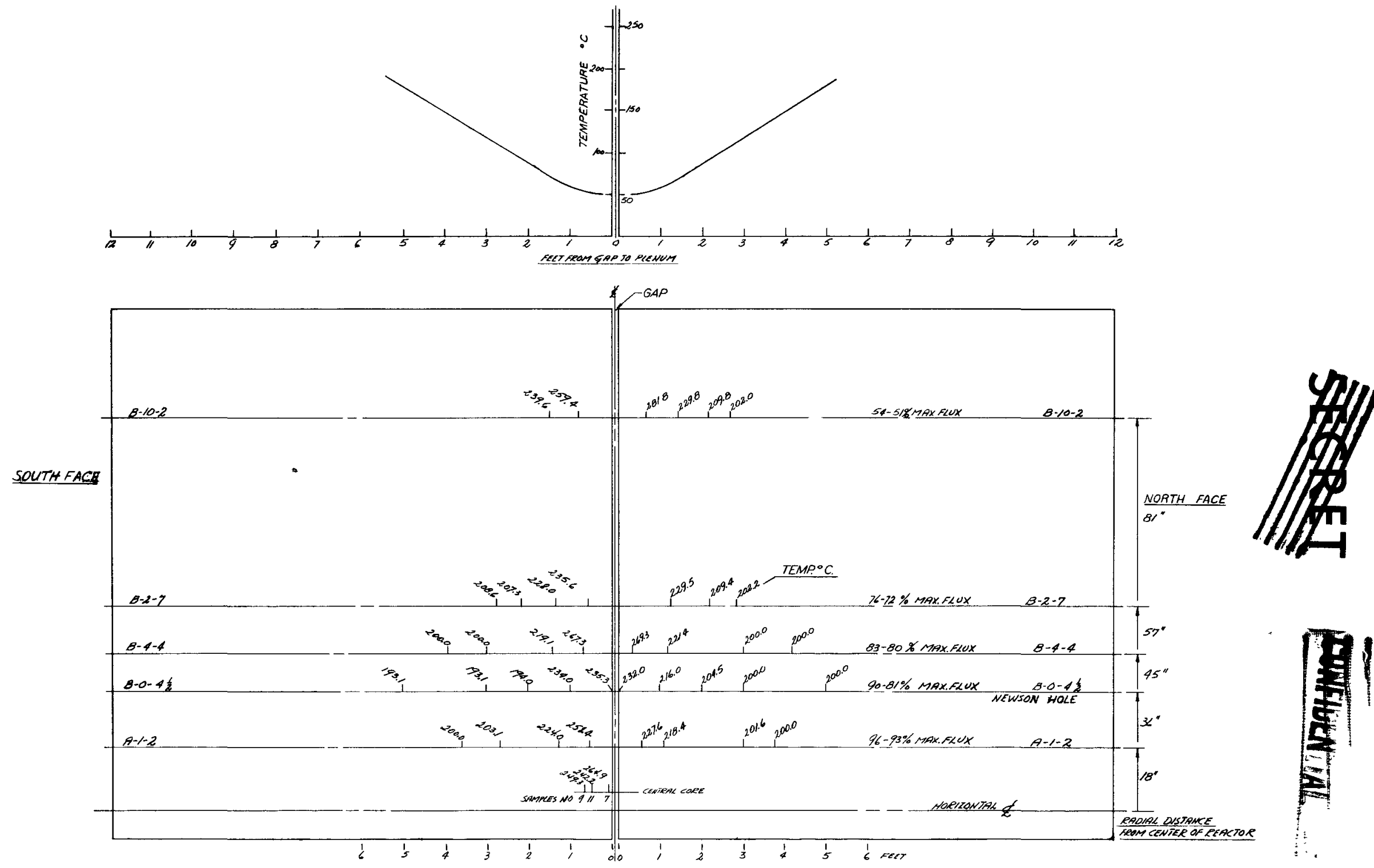

Figure 2. Maximum temperatures in energy release experiment as a function of flux and position. BNL Log No. D-2473. 


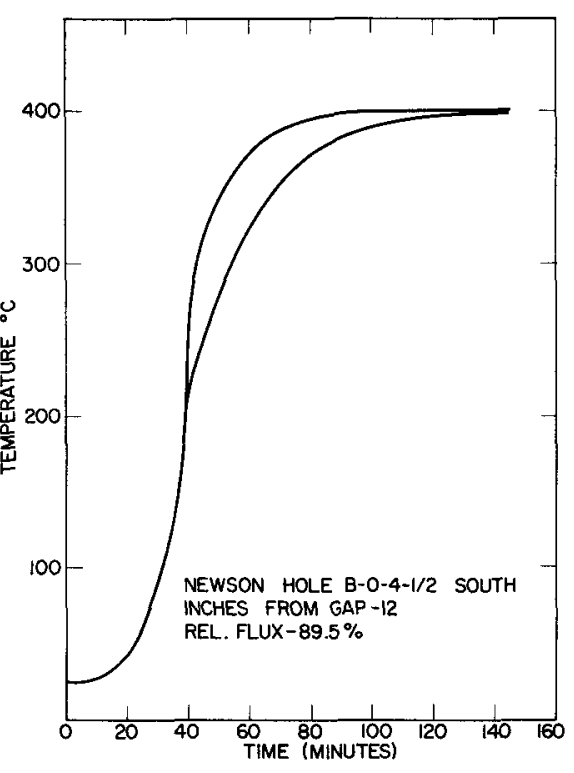

Figure 7. BNL Log No. D-2451.

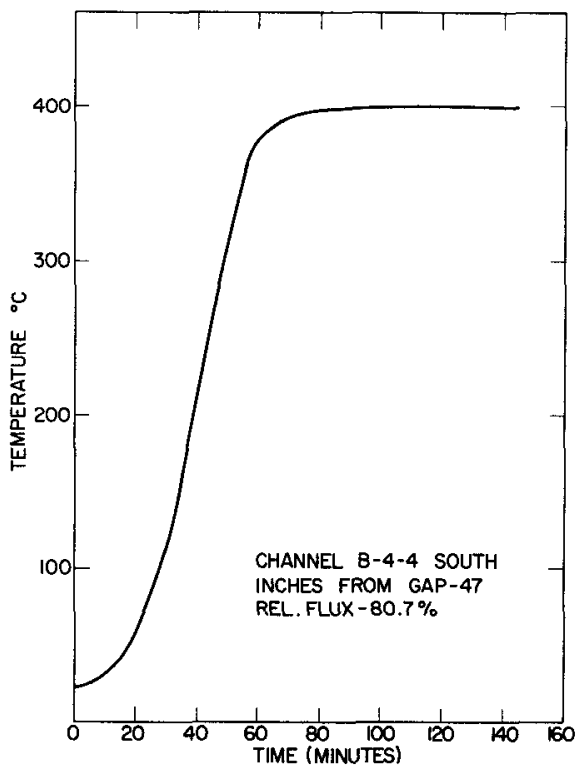

Figure 9. BNL Log No. D-2453.

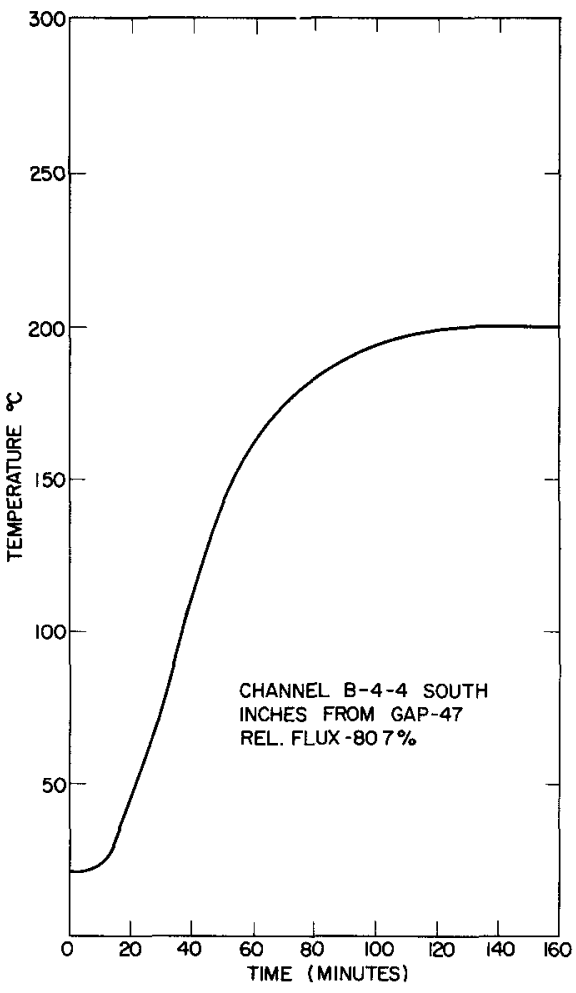

Figure 8. BNL Log No. D-2471.

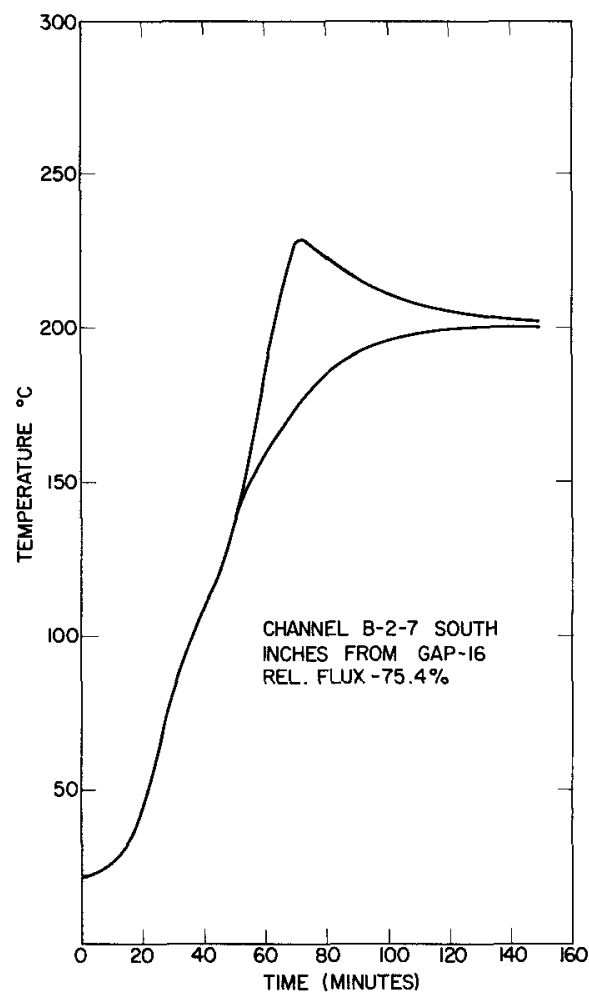

Figure 10. BNL Log No. D-2444. 


\begin{tabular}{|cccccc|}
\hline \multicolumn{7}{c|}{ Table I } \\
\multicolumn{7}{|c|}{ Stored Energy in Various BNL Graphite Samples } \\
\hline $\begin{array}{c}\text { Data from } \\
\text { figure }\end{array}$ & Furnace temp. ${ }^{\circ} \mathrm{C}$ & $\begin{array}{c}\text { Max. temp. reached by } \\
\text { irradiated sample }\end{array}$ & $\begin{array}{c}\text { Mass of } \\
\text { sample (g) }\end{array}$ & Total energy \\
released (cal) & Energy released \\
(cal/g)
\end{tabular}

by Hanford for stored energy from $0^{\circ}$ to $250^{\circ} \mathrm{C}$ is approximately $25 \mathrm{cal} / \mathrm{g}$. This value should be compared to that calculated from Figure 4 which is for a central core sample. The stored energy calculated for this run on a central core sample is $47 \mathrm{cal} / \mathrm{g}$. (See Table I). This apparent difference obtained by the two methods for measuring energy storage may be explained in one of two ways - the samples run by Hanford were different from the sample used in run 4 or the two methods give different results. The former explanation is the more likely one since other central core samples, which were run in this laboratory, gave rise to lower maximum temperatures, i.e. lower energy releases, which compare favorably with the results obtained by Hanford.

The stored energy may be roughly calculated by obtaining the product of the tem perature rise, i.e. the difference between the break away temperature and the maximum temperature attained, and the average specific heat of graphite, .25 to $.30 \mathrm{cal} / \mathrm{g} /{ }^{\circ} \mathrm{C}$. The sharper the peak for the maximum temperature the better the approximation. Values calculated in this manner agree reasonably well with those calculated by Chernick but are apt to be lower. For example, in Figure 4 the temperature difference is about $135^{\circ} \mathrm{C}$, thus the energy released is approximately $40 \mathrm{cal} / \mathrm{g}$, whereas the value obtained by Chernick is $47 \mathrm{cal} / \mathrm{g}$. It appears that maximum temperature attained is a reasonable measure of energy release.

\section{Discussion of Results}

In the section on method of measurement it was pointed out that the se release experiments as conducted could be considered essentially adiabatic. The question of whether the experiments were designed to give the maximum temperature attainable under any set of conditions as a result of the energy release must be considered. From the shape of the curves obtained this question can be answered in the affirmative. How ever if the experiments were truly adiabatic the maximum temperature reached would be higher than that actually attained. The reason for not attaining the higher temperature in the actual experiments is due to the heat loss to the insulator. This however does not affect the calculation on the energy storage. The more exact calculation of stored energy does take this loss into account.

The shape of the curve is to some extent dependent on the size of the specimen in that a larger specimen is actually run under more adiabatic conditions. From the experiment on the large specimen (Figure 12) it is seen that the shape of the curve is changed in the region beyond the temperature maximum: the curve does not turn down as quickly in the large specimen as in the small one. The experiments as run should be comparable to an actual energy release in the pile because in all probability the release will occur in individual blocks rather than from the unit as a whole.

The results obtained in this study show the direct relationship between energy stored in the pile graphite and the temperature of the pile graphite (therefore the

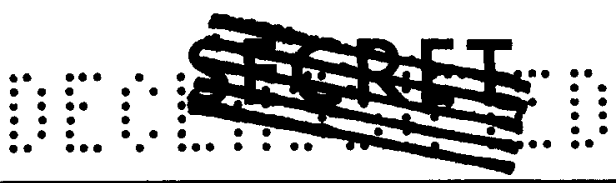



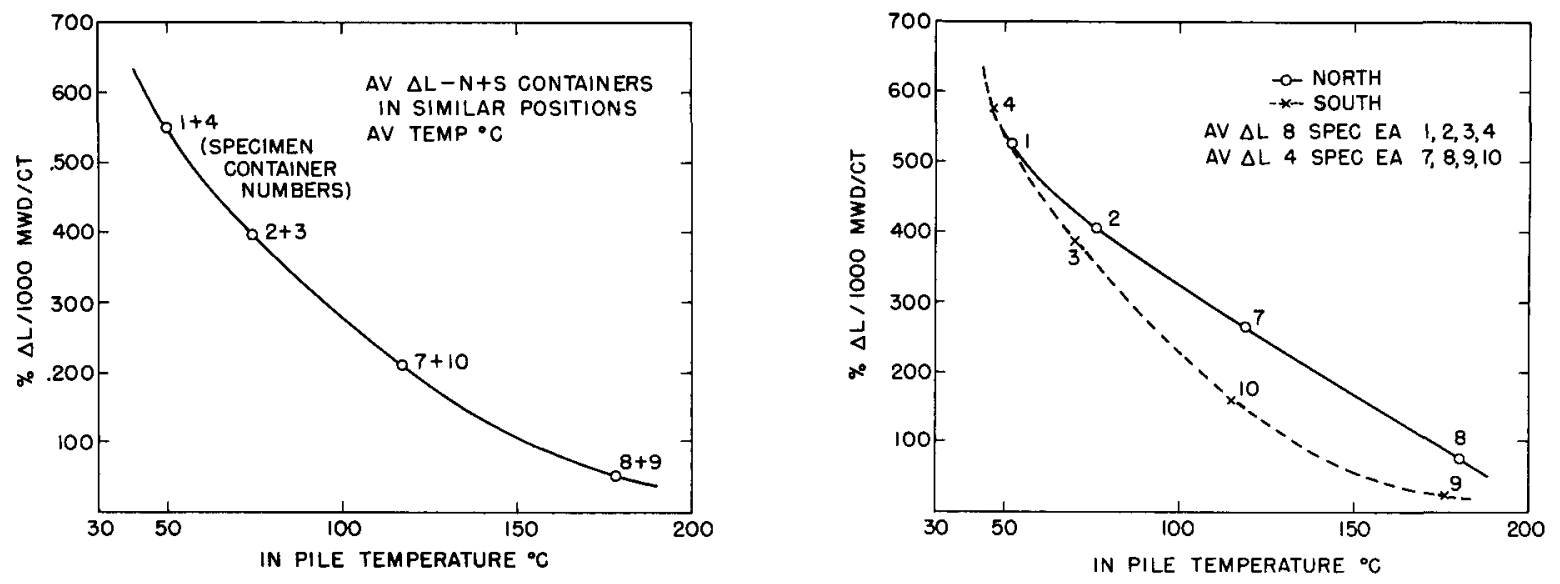

Figure 14 (Left). Percent growth/1000 Mwd/ct of interlayer (Newson) graphite as a function of temperature. BNL Log No. D-2482.

Figure 15 (Right). Percent growth/1000 Mwd/ct of interlayer (Newson) graphite as a function of temperature. BNL Log No. D-2483.

four were chosen after the original measurements were made; one specimen was heattreated at $250^{\circ} \mathrm{C}$ for $1 \mathrm{hr}$ in a vacuum furnace and the other at $400^{\circ} \mathrm{C}$ to determine the recovery of growth at the se temperatures. The vacuum in all cases was less than $5 \mu$. Figure 13 shows the layout of the specimens in the Newson hole containers. Table II shows the samples that were used at the $250^{\circ} \mathrm{C}$ and $400^{\circ} \mathrm{C}$ anneals.

Figure 16 shows the growth and the recovery of a composite of specimens annealed at $250^{\circ} \mathrm{C}$. The results of the $400^{\circ} \mathrm{C}$ heat treatment are shown in Figure 17. Recovery ranging from 24 percent to 36 percent was noted as a result of the $400^{\circ} \mathrm{C}$ heat treatment. In general the amount of recovery depended on the amount of growth. Table III is a summary of the data presented in Figures 14 through 17 .
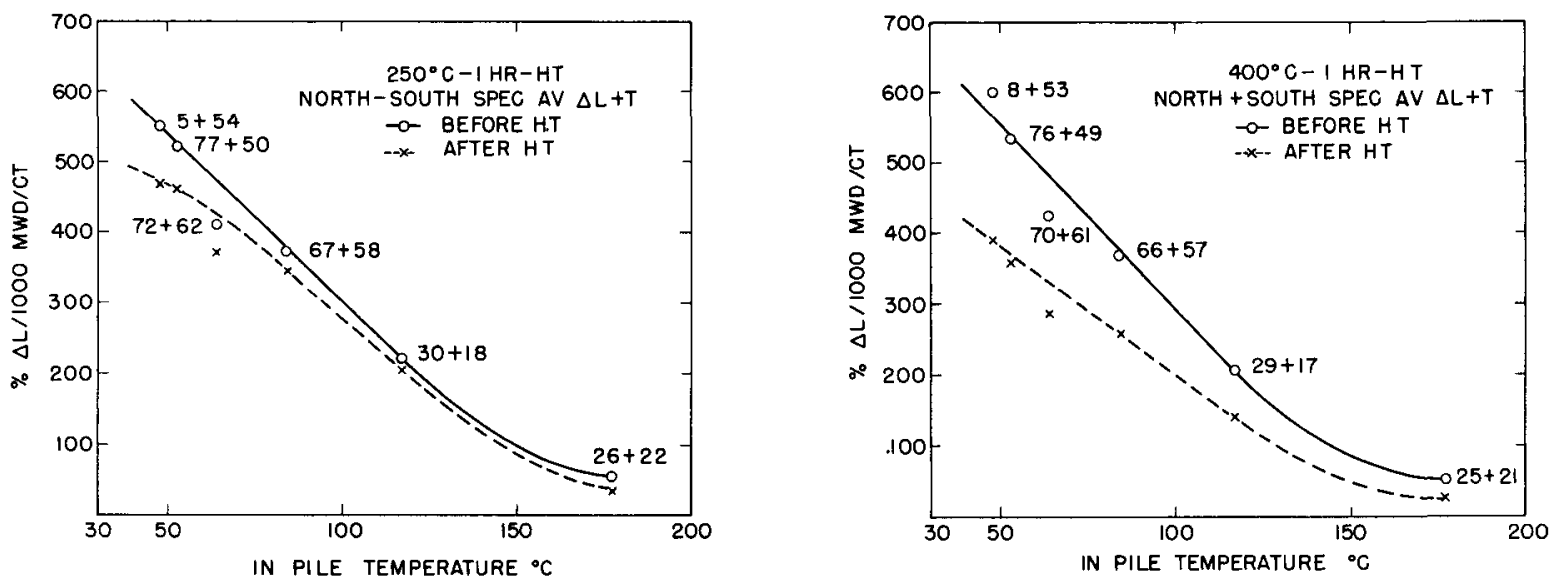

Figure 16 (Left). Comparison of composite curves of growth and recovery as a function of temperature of exposure. BNL Log No. D-2489.

Figure 17 (Right). Comparison of composite curves of growth and recovery as a function of temperature of exposure. BNL Log No. D-2490. 


\begin{tabular}{|c|c|c|c|c|c|c|}
\hline \multicolumn{7}{|c|}{ Table IV } \\
\hline \multicolumn{7}{|c|}{ c-Axis Growth and Recovery Data; specimens from north half of pile. } \\
\hline Channel & $\begin{array}{l}\text { Inches } \\
\text { from gap }\end{array}$ & $\begin{array}{c}\text { c-Axis } \\
\text { after } \\
\text { irradiation }\end{array}$ & $\begin{array}{l}\text { c-Axis } \\
\text { after } \\
\text { anneal }\end{array}$ & $\begin{array}{c}\% \text { Recovery } \\
\text { due to } \\
\text { anneal } * *\end{array}$ & $\begin{array}{c}\text { Exposure } \\
\text { Mwd/ct }\end{array}$ & $\begin{array}{l}\text { Expansion } \\
1000 \mathrm{Mwd} / \mathrm{ct}\end{array}$ \\
\hline \multirow[t]{4}{*}{$B-10-2$} & 32 & 6.824 & 6.816 & 8 & 326. & 4.6 \\
\hline & $25-3 / 4$ & 6.842 & 6.836 & 5.1 & 329. & 5.3 \\
\hline & 17 & 6.87 & 6.864 & 4.1 & 327. & 6.6 \\
\hline & 8 & 6.902 & 6.858 & 24.7 & 322. & 8.2 \\
\hline \multirow[t]{4}{*}{$B-4-4$} & 50 & 6.78 & 6.768 & 21.4 & 468 & 1.8 \\
\hline & 36 & 6.82 & 6.802 & 18.8 & 488 & 2.9 \\
\hline & 14 & 6.912 & 6.868 & 23.4 & 491. & 5.7 \\
\hline & 4 & 6.93 & 6.884 & 22.3 & 481 & 6.4 \\
\hline \multirow{2}{*}{$B-2-7$} & 34 & 6.828 & 6.830 & $\cdots$ & 457. & 3.4 \\
\hline & 15 & 6.9 & 6.876 & 13.6 & 459 & 5.7 \\
\hline \multirow[t]{4}{*}{ A-1-2 } & 45 & 6.788 & 6.788 & $-\cdots$ & 532. & 1.8 \\
\hline & 36 & 6.822 & 6.818 & 4.08 & 543. & 2.7 \\
\hline & 13 & 6.888 & 6.872 & 9.8 & 545. & 4.5 \\
\hline & 7 & 6.902 & 6.860 & 23.6 & 538. & 4.9 \\
\hline \multirow[t]{5}{*}{$B-0-4-1 / 2 *$} & 60 & 6.747 & 6.746 & $-\cdots$ & 308. & 1.3 \\
\hline & 36 & 6.778 & 6.778 & --- & 342 . & 2.4 \\
\hline & 24 & 6.801 & 6.794 & 9.1 & 347. & 3.3 \\
\hline & 12 & 6.827 & 6.814 & 12.6 & 341. & 4.4 \\
\hline & 0 & 6.842 & 6.826 & 13.6 & 337. & 5.1 \\
\hline $\begin{array}{r}\text { Calculation } \\
\text { * Newson h } \\
\text { * Annealed }\end{array}$ & $\begin{array}{l}\text { d on c-axi } \\
\text { amples. }\end{array}$ & 724 (uncor & d for $p$ & ration of bc & $\begin{array}{l}\text { or non-ir } \\
200^{\circ} \mathrm{C} \text {. }\end{array}$ & ted graphite. \\
\hline
\end{tabular}

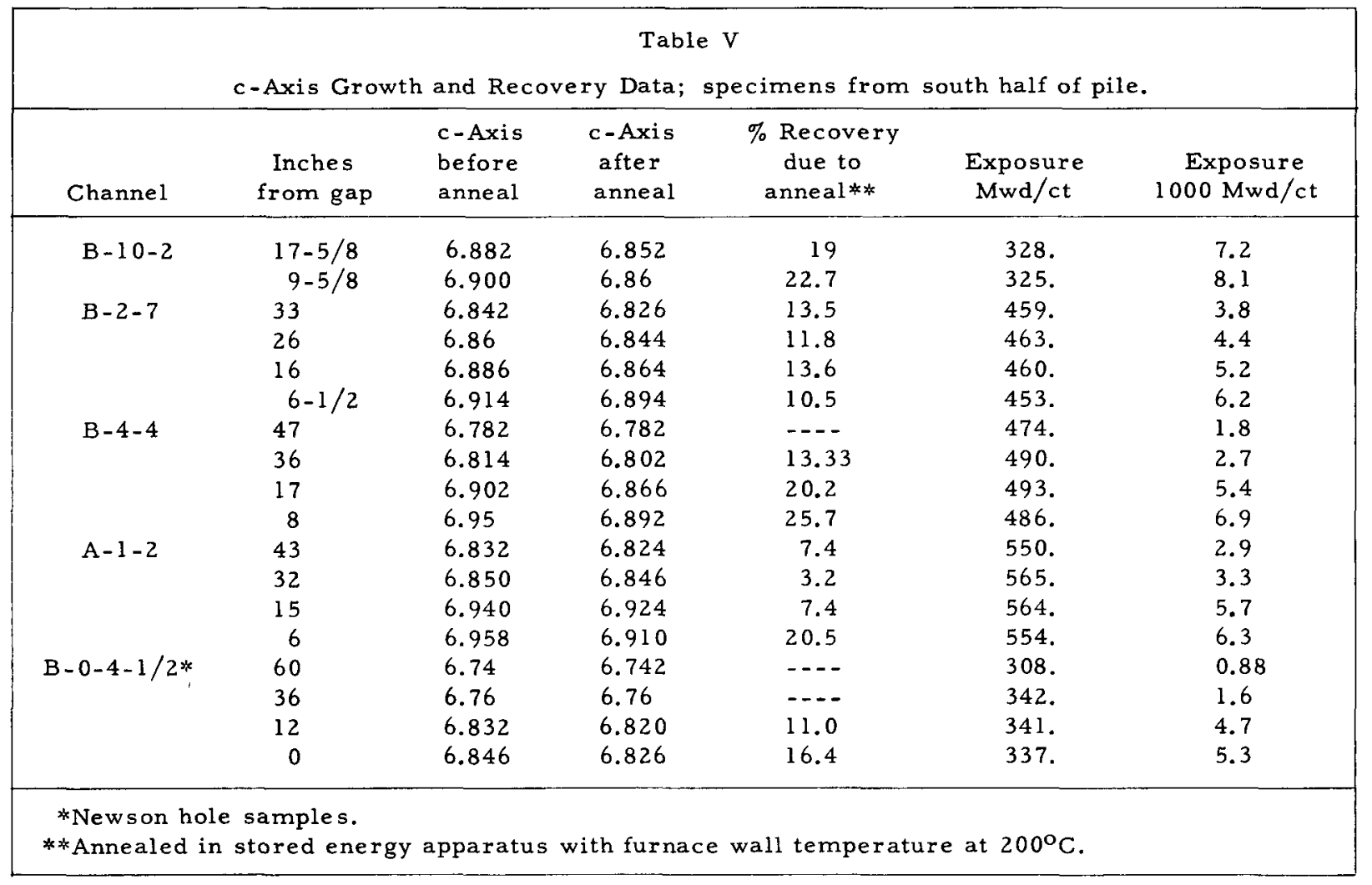


c) Some growth recovery should be expected although the amount of recovery is hard to predict for a complex graphite structure, such as the reactor, from the study of individual pieces of graphite.

d) It seems desirable to anneal the BNL pile graphite.

\section{Acknowledgements}

The authors wish to acknowledge the assistance of $B$. Turovlin for some preliminary work on stored energy, and of I. Kaplan for many helpful discussions. Thanks are due to R.W. Powell not only for devising and obtaining the cored channel specimens but also for consideration given to the many requests made of him.

\section{Addendum}

Since the main body of this report was written, the BNL reactor was annealed dur ing the week of October 19, 1953. The temperature of the pile was increased at a rate of approximately $10^{\circ} \mathrm{C} / \mathrm{hr}$ until parts of the pile reached $300^{\circ} \mathrm{C}$. The pile was then allowed to cool of its own accord (i.e., no air was passed through it) for about $12 \mathrm{hr}$. The cooling was then accelerated by passing air through it.

During the annealing there were no drastic increases in the temperature rate; changes in the shape of the temperature curve were noticed but these changes were slight. Thus, as was expected from the way the anneal was conducted, the energy release occured very closely in an isothermal manner.

Measurements were made to determine the recovery of the growth of graphite at the gap. The greatest recovery measured was $.096 \mathrm{in}$. which is about a 23 percent recovery of the actual growth of the structure. The average recovery was about $.077 \mathrm{in}$.

Post-anneal studies are being conducted. A full account of the results obtained will be is sued as a supplement to this report. 